\title{
Acetylcholinesterase and butyrylcholinesterase inhibitory activity of some selected Nigerian medicinal plants
}

\author{
Taiwo O. Elufioye, ${ }^{1}$ Efere M. Obuotor, ${ }^{2}$ Afolake T. Sennuga, ${ }^{2}$ Joseph M. Agbedahunsi, ,3 \\ Saburi A. Adesanya ${ }^{1}$
}

\author{
${ }^{1}$ Department of Pharmacognosy, Faculty of Pharmacy Obafemi Awolowo University, Ile-Ife, Nigeria, \\ ${ }^{2}$ Department of Biochemistry, Obafemi Awolowo University, Ile-Ife, Nigeria, \\ ${ }^{3}$ Drug Research and Production Unit, Faculty of Pharmacy Obafemi Awolowo University, Ile-Ife, Nigeria.
}

\begin{abstract}
RESUMO: "Atividade inibitória da acetilcolinesterase e butirilcolinesterase de algumas plantas medicinais da Nigéria". As plantas podem ser úteis para estimular a memória, bem como serem usadas para combater o envelhecimento. Vinte e duas plantas, de dezesseis famílias, foram investigadas in vitro oara verificar sua atividade inibidora das enzimas acetilcolinesterase (AChE) e butirilcolinesterase $(\mathrm{BuChE})$ pelo método espectrofotométrico de Ellman in situ e métodos de bioautografia utilizando fisostigmina como padrão. Pelo menos três partes morfológicas de cada planta foram analisadas e a concentração de ensaio foi de $42,5 \mu \mathrm{g} / \mathrm{mL}$. Algumas plantas foram ativas em ambas as enzimas, embora com algumas partes mais ativas que outras. A casca da raiz de Spondias mombin apresentou a maior atividade as duas enzimas, 64,77\% para AChE e 83,94\% para BuChE. Outras partes das plantas selecionadas apresentaram boa seletividade em suas ações. As plantas seletivamente ativos contra AChE foram as casca do caule e casca da raiz de Alchornia laxiflora (41,12\%), e casca da raiz de Callophyllum inophyllurn (56,52\%). As folhas de C. jagus (74,25\%), folhas de Morinda lucida (40,15\%), folhas e casca do caule de Peltophorum pterocarpum (49,5\% e 68,85\%, respectivamente), physiostigmine inibiu 90,31\%. Em geral, atividades melhoras foram apresentadas contra BuChE. Folhas, casca da raiz e casca do caule Bombax bromoposenze foram particularmente ativos. A inibição foi acima de 80\%. Outras partes de algumas espécies também foram seletivas, como as partes aéreas de Antiaris africana, Cissampelos owarensis (78,96\%), folhas e casca do caule de Combretum molle (90,42\% e 88,13\%, respectivamente), casca da raiz e de tubérculos de Dioscorea dumentorum (mais de 87\%), folhas de G cola, cascas de raiz de Markhamia tomentosa, casca do caule de Pycnanthus angolensis e folhas de Tetrapleura tetraptera. A maioria destas plantas são utilizadas como alimentos ou ingredientes alimentares na Nigéria e podem ser responsáveis pela baixa incidência da doença de Alzheimer no país e desempenhar determinadas funções na mediação da doença.
\end{abstract}

Unitermos: Plantas medicinais, acetilcolinesterase, butrilcolinesterase, perda da memória.

\begin{abstract}
Plants have been found to be useful as memory enhansers as well as antiaging. Twenty two of such plants from sixteen families were investigated for their acetylcholinesterase (AChE) and butyrylcholinesterase (BuChE) inhibitory activities using the in vitro Ellman's spectrophotometric and in situ bioautographic methods with physostigmine as standard. At least three morphological parts were examined for each of the plants investigated and the test concentration was $42.5 \mu \mathrm{g} /$ $\mathrm{mL}$. Some plants were active on both enzymes though with some morphological parts being more active than others. The root bark of Spondias mombin showed the highest activity to the two enzymes; $64.77 \%$ and $83.94 \%$ on AChE and BuChE respectively. Other plant parts of the selected plants exhibited some remarkable selectivity in their actions. Those selectively active against AChE were Alchornia laxiflora stem bark $(41.12 \%)$ and root bark, Callophyllum inophyllurn root bark (56.52\%). The leaves of C. jagus (74.25\%), Morinda lucida leaves (40.15\%), Peltophorum pterocarpum leaves and stem bark ( $49.5 \%$ and $68.85 \%$, respectively), physiostigmine gave $90.31 \%$ inhibition. Generally higher activities were found against BuChE. Bombax bromoposenze leaves, root bark and stem bark were particularly active. The inhibition was over $80 \%$. Other selective plant parts are the leaves Antiaris africana, Cissampelos owarensis aerial parts (78.96\%), Combretum molle leaves and stem bark (90.42\% and $88.13 \%$, respectively), Dioscorea dumentorum root bark and tuber (over 87\%), G. kola leaves, Markhamia tomentosa root bark, Pycnanthus angolensis stem bark and Tetrapleura tetraptera leaves. Most of these plants are taken as food or are food ingredients in Nigeria and may account for the low incidence of Alzheimer's disease in the country and may play certain roles in the mediation of the disease.
\end{abstract}




\section{INTRODUCTION}

In Nigeria ethnomedicine, Alzheimer's disease (AD) is not well defined. However, senile conditions are observed amomg the aged which could be due to neurodegeneration. Some plants used in Indian and Chinese traditional medical practice have been justified as having potentials in the management of CNS related disorder. Bacopa monniera and Gingko biloba from Indian and Chinese traditional medicine respectively are well documented cognitive enhancers (Das et al, 2002). Phytochemical analysis of such plants led to the characterization of cyanotroside from Cynanchum atratum and zeathin from Fiatoua villosa as potent $\mathrm{AChE}$ inhibitors (Lee et al., 2004, Heo et al., 2002). Houghton et al 2004 has reported the cholinesterase inhibitory activity of two Nigerian Crinum species i.e. Crinum jagus and Crinum glaucum, which could justify their use as memory enhancers. It is also known that physiostigmine, a potent $\mathrm{AChE}$ inhibitor, was isolated from Physiostigma venenosu (Calabar bean), a medicinal plant native to Nigeria.

Acetylcholine is critical for an adequately functioning memory, and it is the subject of the majority of research looking for treatments for memory defects, like those found in Alzheimer's disease. Any mental health issue that involves memory or lack thereof, directly or indirectly relates to acetylcholine.

Loss of this neurotransmitter plays an instrumental role in the pathogenesis of AD. Postmorterm studies of AD patients consistently have demonstrated the loss of basal forebrain and cortical cholinergic neurons and the depletion of choline acetyltranferase, the enzymes responsible for acetylcholine synthesis. It is also known that the central cholinergic system plays a key role in the retrieval and storage of memory items in the central nervous system (CNS) of mammals (Taylor, 1991, Costa et al., 1999, Okello et al., 2004). There is increasing evidence that cognitive dysfunction due to loss or decline of cholinergic activity in the key areas of the brain, involved in cognition is a normal biological process associated with aging as well as some forms of progressive neurodegenerative disorders such as Alzheimer's disease (AD) (Perry et al., 1996). The decline of cholinergic activity can be ameliorated by agents that restore or enhance cholinergic transmission in the synaptic cleft (Grantham \& Geerts, 2002). Current therapeutic strategies for the symptomatic treatment of Alzheimer's disease and other related disorders such as vascular dementia and dementia with Lewy bodies are aimed at enhancing the associated cholinergic deficit by inhibiting acetylcholinesterase (AChE) (Rosler et al., 1999) resulting in a boost in endogenous level of acetylcholine $(\mathrm{ACh})$ in the brain and an improvement of the cognitive function (Costa et al, 1991, Nordberg et al., 2001: Giacobini et al., 2002).

Although the precise role of $\mathrm{BuChE}$ in the pathogenesis of most dementia disorders have not been unequivocally delineated, it has however been observed that $\mathrm{BuChE}$ increases in the brain of $\mathrm{AD}$ patients. It has been suggested that inhibition of both enzymes may be important in the management of cognitive deficits associated with the AD (Greig et al., 2001, Ghayur et al., 2008) from our survey (unpublished work) some plants are used as memory enhansers and anti aging. Some of these plant are compiled and investigated for their $\mathrm{AChE}$ and BuChE inhibitory activities in order to ascertain their role in the traditional management of memory loss.

\section{MATERIALS AND METHODS}

\section{Plant material}

The various plant parts were collected from Obafemi Awolowo University (O.A.U), Ile-Ife, Nigeria Campus and authenticated by Dr. H. Iloh of the Botany Department, Obafemi Awolowo University, Ile-Ife. Herberia specimen of all the plants were prepared and voucher specimens deposited at the Herbarium located at the Department of Botany, O.A.U. Other details are as presented on Table1.

\section{Chemicals}

Acetylcholinesterase (EC.3.1.1.7) from electrical eel and butrylcholinesterase (EC 3.1.1.8) from horse serum were products of Fluka Co., Germany. Acetylthiocholine iodide (ATChI), butyrylthiocholine chloride (BTChCl), 5:5-dithiobis-2-nitrobenzoic acid (DTNB), eserine and sodium bicarbonate were purchased from Sigma Co. UK. Buffers and other chemicals were of analytical grade.

\section{Extraction of samples}

Fresh samples of the various plant parts were oven dried (the leaves and flower at $40^{\circ} \mathrm{C}$, while root bark and stem bark were at $60^{\circ} \mathrm{C}$ ). The different plant parts were separetely milled into powder. The powdered plant parts were soaked with $80 \%$ methanol for $72 \mathrm{~h}$; the extracts were filtered and concentrated in vacuo using rotary evaporator at $40{ }^{\circ} \mathrm{C}$. The extracts were reconstituted in methanol to obtain a $1 \mathrm{mg} / \mathrm{mL}$ stock solution.

\section{Cholinesterase assay}

Acetycholinesterase and butyrylcholinesterase were respectively carried out using the colorimetric method of Ellman et al. (1961). The reaction assay mixture consisted $2000 \mathrm{~mL} 100 \mathrm{mM}$ phosphate butter pH8.0, $100 \mathrm{ml}$ of test sample stock solution in methanol (a final concentration of $42.5 \mu \mathrm{g} / \mathrm{mL}$ ), $100 \mathrm{~mL}$, of enzyme AChE or BuCHE solution at a final concentration of $0.03 \mathrm{U} / \mathrm{mL}$ and $0.01 \mu / \mathrm{mL}$ respectively, $100 \mu \mathrm{L}$ of DTNB $(0.3 \mathrm{mM})$

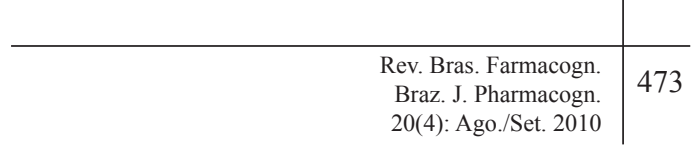


prepared in $100 \mathrm{M}$ phosphate buffer $\mathrm{pH} 7.0$ containing $120 \mathrm{mM}$ sodium bicarbonate. The reaction mixture was vortexed and then pre-incubated in a water bath at $37{ }^{\circ} \mathrm{C}$ for $30 \mathrm{~min}$. The reaction was then initiated by the addition of $100 \mu \mathrm{L}$ of ATCI or BTCI at a final concentration of $0.5 \mathrm{mM}$ as a negative control. The inhibitor solution was replaced with methanol. The change in absorbance at $\lambda$ $412 \mathrm{~nm}$ was then measured for a period of $5 \mathrm{~min}$ at ambient temperature. All assays were carried out in triplicate. The final concentration of the sample was $42.5 \mu \mathrm{g} / \mathrm{mL}$. Eserine (-) physiotigmine) was used as positive control at same concentration. The $\%$ inhibition was calculated as follows:

$$
\%=\frac{a-b}{a} \times 100
$$

Where: $\mathrm{a}=\Delta \mathrm{A} / \mathrm{min}$ of control; $\mathrm{b}=\Delta \mathrm{A} / \mathrm{min}$ of test sample; $\Delta \mathrm{A}=$ Change in absorbance.

\section{RESULTS AND DISCUSSION}

The selective cholinergic neurodegeneration forms the basis for the so-called cholinergic hypothesis of cognitive hypofunction (Perry et al., 1996; Perry et al., 1998; Bartus et al., 1982), that postulates that many of the cognitive, functional and behavioral symptoms experienced by patients with cognitive dysfunction results from a deficiency in neurotransmitter $\mathrm{ACh}$, and thus in cholinergic neurotransmission. Numerous pharmacological and lesion studies in animals have been shown to support the involvement of central cholinergic systems in learning and memory (Camps \& Munoz-Torrero, 2002).

The cholinergic hypothesis for cognitive hypofunction has provided the rationale for the current major therapeutic approach to cognitive dysfunction: which holds that the enhancement or restoration of central cholinergic function may significantly improve the cognitive impairments present in cognitive disorders (Francis et al., 1999). Currently, the only approved therapies for cognitive dysfunction are a group of indirect cholinomimetics which enhance function by inhibiting ACh degradation.

Cholinesterase inhibitors (ChEI), most especially of $\mathrm{AChE}$, however constitute, to date, the most effective approach to treat the cognitive symptoms of AD (Giacobini, 2002). They have shown clear therapeutic utility on both cognitive performances, as well as on the quality of life in these patients (Francis et al, 1999). Indeed, the only drugs currently approved for the treatment of cognitive disorders are $\mathrm{AChEI}$ (e.g. tacrine, donepezilm rivastigmine and galanthamine). A large amount of AChEI has been developed, which differ among themselves in selectivity for $\mathrm{AChE}$ and BuChE, mechanism of inhibition and reversibility.

Twenty two plants from sixteen diferent families i.e. Amaryllidaceae, Anacardiaceae, Apocynaceae,
Bignoniaceae, Bombacaceae, Combretaceae, Convovulaceae, Dioscoreaceae, Euphorbiaceae, Guttiferaceae, Fabaceae, Menispermaceae, Moraceae, Myristicaceae, Rubiaceae, and Solanaceae were investigated for their $\mathrm{AChE}$ and $\mathrm{BuChE}$ activities in this study.

Alchornia laxiflora, Croton zambesicus, Jatropha curcas and Jatropha tangorensis all belonging to the Euphorbiaceae all showed weak (40-49\%) activity towards both $\mathrm{AChE}$ and BuChE at $42.5 \mu \mathrm{g} / \mathrm{mL}$ except Croton zambesicus whose activity was moderately high (51.29\%) towards AChE.

In the Bombaceae family, Bombax bromoposenze and Ceiba pentadra both showed low activity towards AchE (below 19\%). However, Bombax bromoposenze showed very high activity towards $\mathrm{BuChE} \mathrm{(>83 \% ).} \mathrm{All} \mathrm{the}$ extracts of the different morphorlogical parts tested showed similarly high BuChE activity. This BuChE selective activity was also noted in the Dioscoreaceae family, $>87 \%$ inhibition of BuChE was observed in the tubers and roots of Dioscorea dumetorum, leaves of Garcinia kola (86.46\%) (Guttiferaceae), Combretum molle (Combretaceae), Cissampelos owarensis (Menispermaceae), rootbark of Markhamia tomentosa (Bignoniaceae) and the leaves of Tetrapleura tetraptera (Leguminoceae). Plants studied in this family gave $>78 \%$ inhibition of BuChE while activity against AChE was rather low $(<24 \%)$.

The leaves of Crinum jagus (Amaryllidaceae), stembark of Peltophorum pterocarpum (Leguminosae), stembark of Pycnanthus angolensis (Myristicaceae), rootbark and stembark of Spondias mombin (Anarcardiaceae) all gave high AChE inhibition activity $(>60 \%)$. Pycnanthus angolensis and Spondias mombin gave high activity in both $\mathrm{AChE}$ and BuChE. Their stem bark and root bark gave $\mathrm{BuChE}$ inhibition $>80 \%$.

Other plants studied, including Antaiaris africana (Moraceae), Capsicum frutensis (Solanaceae), Hollarhena floribunda (Apocynaceae) and Ipomea involucrata (Convovulaceae) all gave weak activity $(<40 \%)$ towards the enzymes.

This non-selectivity of some anti-ChE has been adduced to the structural and functional homology between degrade acetylcholine and the continued use of ChEI with the dual ability to inhibit AChE and BuChE have been implicated in the number of side effects associated with some cholinesterase inhibitors presently in use. However, it has been speculated that this duality could lead to improved clinical outcomes, particularly in respect to the management of Alzheimer's disease (Greig et al, 2001). Thus the development of selective AChE inhibitors has been a primary challenge still confronting anticholinesterase pharmacology to date. While AChE is very specific in its substrate recognition and requirement, $\mathrm{BuChE}$ reconizes a broad range of substrates. For this reason, it has been suggested that circulating plasma BuChE could possibly be serving a scavenging function thereby protecting 
Table 1. Anticholinesterase activity of the plant extract against acetylcholine esterase (AChE) and buryrylcholine esterase (BuChE).

\begin{tabular}{|c|c|c|c|c|}
\hline \multirow{2}{*}{ Plant species (IFE $N^{\circ}$ ) Family } & \multirow{2}{*}{ Plant Part } & \multicolumn{2}{|c|}{ Percentage Inhibition $(42.5 \mu \mathrm{g} / \mathrm{mL})$} & \\
\hline & & AChE & $\mathrm{BuChE}$ & \\
\hline Alchornea laxiflora (IFE 2505) Euphorbiaceae & Leaves & $25.38+2.44$ & 0 & \\
\hline Alchornea laxiflora & Root bark & $31.47+1.07$ & 0 & \\
\hline Alchornea laxiflora & Stem bark & $41.12+1.54$ & $23.71+0.57$ & \\
\hline Antiaris africana (IFE4187) Moraceae & Leaves & $4.39+0.41$ & $78.55+3.97$ & \\
\hline Antiaris Africana & Root bark & $7.02+0.46$ & $31.15+2.40$ & \\
\hline Antiaris Africana & Stem bark & $13.45+0.82$ & $15.61+1.31$ & \\
\hline Bombax bromoposenze (IFE 2257) Bombacaceae & Leaves & $14.33+1.91$ & $83.98+6.26$ & \\
\hline Bombax bromoposenze & Root bark & $0.29+0.01$ & $89.31+9.22$ & \\
\hline Bombax bromoposenze & Stem bark & $11.11+0.54$ & $88.90+7.27$ & \\
\hline Callophylum inophyllum (IFE 14602) Guttiferaceae & Flowers & $7.89+0.17$ & $0.96+0.09$ & \\
\hline Callophylum inophyllum & Fruits & $4.39+0.44$ & 0 & \\
\hline Callophylum inophyllum & Leaves & $12.28+0.62$ & $0.69+0.08$ & \\
\hline Callophylum inophyllum & Root bark & $56.52+3.97$ & $15.17+0.59$ & \\
\hline Callophylum inophyllum & Stem bark & $31.29+1.22$ & 0 & \\
\hline Capsicum frutensis (IFE 12225) Solanaceae & Leaves & $10.34+0.83$ & $0.85+0.07$ & \\
\hline Capsicum frutensis & Stem bark & $6.71+0.11$ & $3.01+0.44$ & \\
\hline Ceiba pentadra (IFE 2260) Bombacaceae & Root bark & $18.46+1.15$ & 0 & \\
\hline Ceiba pentadra & Leaves & $16.30+0.88$ & $9.06+0.21$ & \\
\hline Ceiba pentadra & Stem bark & $18.99+0.42$ & 0 & \\
\hline Cissampelos owarensis (IFE 14920) Menispermaceae & Aerial part & $19.59+0.81$ & $78.96+7.55$ & \\
\hline Combretum molle (IFE 1942) Combretaceae & Leaves & $12.17+0.15$ & $90.42+5.35$ & \\
\hline Combretum molle & Root bark & $24.72+2.32$ & $88.13+4.21$ & \\
\hline Combretum molle & Stem bark & $12.50+0.67$ & 0 & \\
\hline Crinum jagus (IFE 8701) Amaryllidaceae & Bulb & $42.87+0.5$ & $48.06+0.66$ & \\
\hline Crinum jagus & Leaves & $74.25+6.42$ & $3.61+0.07$ & \\
\hline Crinum jagus & Roots & $40.64+2.55$ & $91.34+6.25$ & \\
\hline Croton zambesicus (IFE 2575) Euphorbiaceae & Leaves & $51.29+3.86$ & $26.26+1.11$ & \\
\hline Discorea dumentorum (IFE 8806) Dioscoreaceae & Leaves & $15.04+1.17$ & $0.24+0.04$ & \\
\hline Discorea dumentorum & Root bark & $4.22+0.19$ & $87.55+7.24$ & \\
\hline Discorea dumentorum & Stem bark & $17.37+0.95$ & $16.45+0.86$ & \\
\hline Discorea dumentorum & Tubers & $21.74+2.03$ & $87.24+4.23$ & \\
\hline Garcinia kola (IFE 13184) Guttiferaceae & Leaves & $0.29+0.01$ & $86.46+5.04$ & \\
\hline Garcinia kola & Root bark & $30.99+1.44$ & $11.86+0.37$ & \\
\hline Garcinia kola & Stem bark & $11.99+0.84$ & $5.93+0.29$ & \\
\hline Hollarhena floribunda (IFE 14597) Apocynaceae & Leaves & $16.31+0.54$ & $0.47+0.08$ & \\
\hline Hollarhena floribunda & Root bark & $22.39+1.21$ & $0.87+0.56$ & \\
\hline Hollarhen a floribunda & Stem bark & $17.12+0.73$ & $25.99+0.82$ & \\
\hline Ipomea involucrata (IFE 6975) Convovulaceae & Aerial part & $25.73+1.41$ & 0 & \\
\hline Jatropha curcas (IFE 2699) Euphorbiaceae & Fruits & $15.74+1.84$ & $3.25+0.62$ & \\
\hline Jatropha curcas & Leaves & $23.86+0.96$ & $3.82+0.33$ & \\
\hline Jatropha curcas & Root bark & $22.84+1.91$ & $0.46+0.01$ & \\
\hline Jatropha curcas & Stem bark & $18.27+1.14$ & $4.39+0.01$ & \\
\hline Jatropha tangorensis (IFE 2700) Euphorbiaceae & Leaves & $17.25+1.04$ & $13.23+1.08$ & \\
\hline Jatropha tangorensis & Stem bark & $2.92+0.06$ & $8.16+0.94$ & \\
\hline Markhamia tomentosa (IFE 7313) Bignoniaceae & Leaves & $18.78+2.77$ & $2.96+0.06$ & \\
\hline Markhamia tomentosa & Root bark & $24.37+1.05$ & $78.45+5.67$ & \\
\hline Markhamia tomentosa & Stem bark & $40.61+4.01$ & $24.82+1.77$ & \\
\hline & & & $\begin{array}{l}\text { Rev. Bras. Farmacogn. } \\
\text { Braz. J. Pharmacogn. } \\
\text { 20(4): Ago./Set. } 2010\end{array}$ & 475 \\
\hline
\end{tabular}




\begin{tabular}{|c|c|c|c|}
\hline Morinda lucida (IFE 5672) Rubiaceae & Leaves & $4015+2.57$ & $34.09+1.93$ \\
\hline Morinda lucida & Root bark & $13.20+0.78$ & $0.78+0.02$ \\
\hline Morinda lucida & Stem bark & $22.34+0.76$ & $2.50+0.06$ \\
\hline Peltophorum pterocarpum (IFE 3171) Leguminoceae & Fruits & $15.68+1.37$ & $4.31+0.22$ \\
\hline Peltophorum pterocarpum & Leaves & $47.5+2.41$ & $4.89+0.71$ \\
\hline Peltophorum pterocarpum & Root bark & $48.46+4.47$ & $51.77+2.20$ \\
\hline Peltophorum pterocarpum & Stem bark & $68.85+3.53$ & $3.05+0.58$ \\
\hline Pycnanthus angolensis (IFE 13039) Myristicaceae & Fruits & $8.44+0.76$ & $9.59+0.32$ \\
\hline Pycnanthus angolensis & Leaves & $43.96+3.04$ & $43.59+1.77$ \\
\hline Pycnanthus angolensis & Root bark & $15.51+0.64$ & 0 \\
\hline Pycnanthus angolensis & Stem bark & $66.52+5.02$ & $86.05+8.32$ \\
\hline Spondias mombin (IFE 9572) Anarcadiaceae & Leaves & $48.58+4.56$ & $47.34+2.55$ \\
\hline Spondias mombin & Root bark & $64.77+2.73$ & $83.94+6.31$ \\
\hline Spondias mombin & Stem bark & $60.71+3.08$ & $48.72+1.49$ \\
\hline Tetrapleura tetraptera (IFE 3391) Leguminosae & Fruits & $22.34+1.90$ & $1.04+0.02$ \\
\hline Tetrapleura tetraptera & Leaves & $1.52+0.01$ & $81.87+3.54$ \\
\hline Tetrapleura tetraptera & Root bark & $34.77+0.66$ & 0 \\
\hline Tetrapleura tetraptera & Stem bark & $24.87+1.32$ & $4.22+0.11$ \\
\hline Physostigmine (Standard) & & $90.31+3.55$ & $84.27+4.72$ \\
\hline
\end{tabular}

AChE from naturally occurring inhibitors. In this regard, $\mathrm{BuChE}$ could also scavenge anticholinesterase drugs, thereby elevating the dose necessary to achieve reasonable inhibitions at the target region of the brain for the effective therapeutic relief (Perry et al., 1996).

While most researches have been geared towards identifying AChE selective inhibitors, recent results has suggest that inhibition of both $\mathrm{AChE}$ and $\mathrm{BuChE}$ should be one of the objectives in the treatment of cognitive dysfunctions associated with cases of AD (Greig et al., 2001). Several researches are now aimed at finding plants that inhibits both enzymes (Okello et al., 2004). Thus, plants that show activity towards either or both enzyme may find some use in the management of memory dysfuntion.

\section{CONCLUSION}

This work shows that most of the plant parts tested showed cholinesterase inhibitory activity towards either $\mathrm{AChE}, \mathrm{BuChE}$ or both enzymes and may be considered for further studies in the management of $\mathrm{AD}$. Plants that selectively inhibits AChE may be more useful in early stages of $\mathrm{AD}$ while those that inhibits both $\mathrm{AChE}$ and BuChE may be of paricular interest in severes cases of $\mathrm{AD}$.

\section{REFERENCES}

Bartus RT, Dean RL, Beer B, Lippa AS 1982. The cholinergic hypothesis of geriatric memory dysfunction. Science 217: 408-417.

Camps P, Munoz-Torrero D 2002. Cholinergic drugs in pharmacotherapy of Alzheimers disease. Mini Rev Med Chem 2: 11-25.
Costa J, Anand R, Cutler N 1991. Correlation between cognitive effects and level of acetylcholine esterase inhibition in a trial with rivastigmine in Alzheimer's patients. Proc Am Psych Assoc, Poster NR561.

Das A, Shanker G, Nath C, Pal R, Singh S, Singh HK 2002. A comparative study in rodents of standardize extracts of Bacopa monniera and Ginkgo biloba anticholinesterase and cognitive enhancing activities. Pharmacol Biochem Behav 73: 893-900.

Ellman GL, Courtney KD, Andres V, Fearstherstone RM 1961. A new rapid colorimetric determination of acetyl cholionesterase activity. Biochem Pharmacol 7: 88-95.

Francis PT, Palmer AM, Snape M, Wil Cock GK 1999. The cholinengic hypothesis of Alzheimer's disease; a review of progress. J Neurol Neurosurg Psychiatry 66: 137147.

Ghayur MN, Gilani AH, Ahmed T, Khalid A, Nawaz AS, Agbedahunsi JM, Choudhary MI, Houghton PJ 2008. Muscarinic $\mathrm{Ca}^{++}$antagonist and specific butyrylcholinesterase inhibitory activity of dried ginger extract might explain its use in dementia. J Pharm Pharmacol 60: 1375-1383.

Giacobini R, Spiegel E, Enz A, Veroff AE, Cutler NR 2002. Inhibition of acetyl and burylcholinesterase in the cerebrospinal fluid of patients with Alzheimer's disease by rivastigmine: correlation with cognitive benefit. $J$ Neural Transm 109: 1053-1065.

Grantham C, Geerts H 2002. The rationale behind cholinergic drug treatment for dementia related to cerebrospinal disease. J Neurol Sci 203: 131-136.

Greig NH, Utsuki T, Yu QU, Zhu X, Halloway HW, PerryT, Lee B, Ingram DK, Lahiri DK, 2001. New therapeutic target in Alzheimer's disease treatment: Attention to butyrylcholinesterase. Curr Med Res Opin 17: 159-165.

Heo HJ, Hong SC, Cho HY, Hong B, Kim HK, Kim EK, Shin DH 2002. Inhibitory effecy of zeatin isolated from Fitoua villosa, on acytycholineterase activity from PC 12 cells. 
Mol Cells 13: 113-117.

Houghton JP, Agbedahunsi JM, Adegbulugbe A 2004. Choline esterase inhibitory properties of alkaloids from two Nigerian Crinum species. Phytochemistry 65: 28932896.

Lee YK, Yoon JS, Kim ES, Kang SY, Kim YC 2004. Anti acethycholinesterase and anti-amnessic activities of a pregnane glycoside, cynatroside B, from Cynanchum atratum. Planta Med 71: 7-11.

Norberge A, Darreh-Shori T, Svenson A, Quan Z 2001. AchE and BuchE activities in CSF of mild AD patients following 12 months of rivastigmine treatment. J Neurol Sci 187 (suppl): PQ 144.

Okello JE, Savelev SU, Perry KE 2004. In vitro anti-secretase and dual anticholinesterase activity of Camellia sinensis L. (tea) relevants to treatment of dementia. Phytother Res 18: 624-627.

Perry N, Court G, Bidet N, Court J, Perry EK 1996. Cholinergic activities of European herbs and potential for dementia therapy. J Ger Psychiatr 11: 1062-1069.

Perry EK, Pirckering AT, Wang WW, Houghton P, Perry NS 1998. Medicinal plants and Alzheimer's disease: integrating ethnobotanical and contemporary scientific evidence. $J$ Altern Complement Med (US) 4: 419-428.

Rösler M, Anand R, Cicin-Sain A, Gauthier S, Agid Y, DalBianco P, Stähelin HB, Hartman R, Gharabawi M, Bayer T 1999. Efficacy and safety of rivastigmine in patients with Alzheimer's disease: international randomised controlled trial. Brit Med J 318: 633-640

Taylor P 1991. The cholinesterase. J Biol Chem 266: 40254028. 